\title{
Drama, History, and Postcolonial Résistance in Northern Nigeria: A Review of Ahmed Yerima's Attahiru
}

\author{
Isyaku Hassan
}

Faculty of Languages and Communication, Universiti Sultan Zainal Abidin

21300 Kuala Terengganu, Malaysia

Mohd Nazri Latiff Azmi

Faculty of Languages and Communication, Universiti Sultan Zainal Abidin 21300 Kuala Terengganu, Malaysia

Mubarak Ibrahim Lawan

Department of English and Literary Studies, Al-Qalam University Katsina, Nigeria

Habibu Awais Abubakar

Kano State College of Education and Preliminary Studies, Nigeria

\begin{abstract}
The relationship between history proper and African historical plays drew much attention of researchers in recent years. Many theatre scholars and playwrights argue that the value of these plays, which were primarily regarded as fiction or imaginative reconstruction of the past, may prevail over history. Theatre, which is considered the most symbolic form of art, can be historically educative and evocatively accurate. Based on the aforesaid arguments, this study aims to explore the dramaturgicals, theatricals or thespians used in Yerima's Attahiru (1999) in order to repudiate and resist the distorted versions of the colonial history of Sokoto Caliphate in an effective and affective way. To achieve this aim, textual analysis is used by combining its important approaches: author-oriented approach and context-oriented approach. This analysis is significant because the researchers investigated the colonial resistance captured in the play through postcolonial theory. In addition, this paper explores the attitudes of the colonialist and the colonised reproduced in the play and how the play helps in the decolonisation process, as well as how the images of the damaged heroes are reconstructed in the play in order to restore national pride and integrity. The play reconstructs and corrects a seriously damaged and awfully misrepresented African spiritual leader, Caliph Attahiru of the old Sokoto Caliphate in Northern Nigeria.

Keywords: Attahiru, drama, Nigeria, postcolonial resistance, Sokoto Caliphate Cites as: Hassan, I. Azmi, M.N.L. Lawan, M.I., \& Abubakar, H. A. (2019). Drama, History, and Postcolonial Résistance in Northern Nigeria: A Review of Ahmed Yerima's Attahiru. Arab World English Journal for Translation \& Literary Studies, 3 (2). 165-176

DOI: http://dx.doi.org/10.24093/awejtls/vol3no2.14
\end{abstract}

Arab World English Journal for Translation \& Literary Studies 